\title{
Analysis of retail marketing strategies on Organizational competitiveness
}

\author{
Isaack Mayienda Obaga ${ }^{1}$, Dr. Karim Omido ${ }^{1}$, Hamadi Musa Garashi ${ }^{1}$, Odhiambo Odera $^{2}$, \\ Prof Martin Ogutu ${ }^{3}$ \\ ${ }^{1}$ Jomo Kenyatta University of Agriculture \& Technology, Taita Taveta Campus, Kenya \\ ${ }^{2}$ University of Southern Queensland, Australia \\ ${ }^{3}$ Department of Business Administration, School of Business, University of Nairobi, Kenya
}

\begin{abstract}
The purpose of this study was to analyze retail marketing strategies on organizational competitiveness. The study attempted to examine the strategies that have been applied and adopted by the retail companies elsewhere in attempt to understand how retailing functions. A descriptive research design was employed in this study. The population was marketing executives in the selected bottling companies in Kenya. Primary data was collected using closed questionnaire. The data collected was organized and presented using descriptive statistics. Correlation analysis was also utilized for data analysis. Findings indicate that the most pursued retail marketing strategies were; marketing segmentation, product strategies, distribution, pricing, marketing relationship and promotions. The findings also suggest that bottling companies rely on combination of strategies as different market segments respond differently hence need for product-specific marketing strategy.
\end{abstract}

Keywords: Retail marketing strategies, organizational competitiveness, Kenya

\section{INTRODUCTION}

The market place is not what it used to be, it is radically changing as a result of major societal forces such as technological advances, globalization, and deregulation. These major forces have created new behaviors and challenges. Kotler (2003) argues that customers increasingly expect higher quality and service and some customization. Extensive product information cab be obtained from the internet and other sources, permitting them to shop more intelligently. They are showing greater price sensitivity in their search for value. Brand manufacturers are facing intense competition from the domestic and foreign brands, which is resulting in rising promotion costs and shrinking profit margins. Store based retailers are suffering from an over saturation of retailing. Store based retailers are facing competition from catalog houses, direct -mail firms, newspaper, magazine, and TV direct -to-consumer ads, home shopping TV, and the Internet. As a result they are experiencing shrinking margins.

It is important therefore to note that the retail sector is constantly changing that those who do not innovate with time will ultimately lose substantially. It is an evolving industry which must cope with the various changes taking place. Jaworski \& Kohli (1993) conclude that the ability of a firm to respond to identified changes in the market or customer behaviour is an important feature exhibited by successful firms. Kotler (2003) notes that today's consumers are able to access objective information on competing brands, including costs, prices, features, and quality, without relying on individual manufacturers or retailers. In many cases they will be able to specify the customized services they want. They will be able to specify the prices they are willing to pay, and wait for the most eager sellers to respond. The result is the dramatic shift of economic power from retailers to consumers.

Sternquist \& Jin (1998) asserts that retailers have been forced to engage in international expansion for a variety of reasons. Key among them are; the desire to reach beyond a mature home market with low growth potential, a need to diversify the investment, intense competition locally and the economic down turn. As a result, companies are changing in a number of ways including; reengineering, outsourcingcommerce, benchmarking, alliances, partner suppliers, and market centered, from being local to both local and global and decentralized.

Marketers are therefore changing their philosophies, concepts and tools in order to survive during this competitive era. Continuous analysis of what is happening in the stores helps a smart retailer to quickly and profitability adapt to the changing customer behavior, buying pattern and monitor various dynamic parameters that determines the success or failure of any retail enterprise (Kotler, 2000).

Bottling companies are faced with numerous challenges including intense competition, satisfying the needs of customers, and development of new products and services among other challenges. In the desire to gain competitive advantages necessitated by macro and micro level changes in the operative business, bottling companies are adopting retail marketing strategies to assist them remain relevant in the business world. Since these firms perform an important role in the economy of the country, it is necessary that they adopt distribution strategies to sustain or increase their market share, expand to new territories or markets, acquire new technologies, develop brand or line extensions, reduce costs and risks (Oliver, 1993). Consumers expect that retailers will offer the right match in terms of right product offering, quantities, place, time, and price by the right appeal. Retailing in Kenya has gone through a significant change in the last couple of years with a complete shift in shopper's expectations and experiences. While the shoppers have remained the same everything has changed and gone mega, ranging from the size of the outlets to the layout, the ambience, the experience, the service, the loyalty and incentives to the way promotions are done. Bottling 
companies in Kenya need to create retail marketing strategies for maintaining their business performances hence the need for this research. This study attempts to comparatively analyze the various retail marketing strategies adapted by the bottling companies in Kenya.

\section{LITERATURE REVIEW}

Davidson et al (2000) clarify retailing as the final part of the marketing process in which the various functions of the seller, usually a store or service establishment, and the buyer, an individual consumer are primarily oriented to accomplishing the exchange of economic goods and services, for purposes of personal, family or household use. Although retailing deals predominantly with the ultimate consumer, it must be recognized that the retail store is only one of several alternative means by which consumers can obtain the products and services they desire. Increasingly, consumer expenditures that might have traditionally gone through the retailing structure are being diverted to other types of consumption markets which are being aggressively served by a variety of both private and public enterprises. Berkowitz et al. (2000) describe retail marketing as all activities involved in selling, renting, and providing services to ultimate customers for personal, non-business use. In the channel of distribution, retailing is where the customer meets the product. It is through retailing that exchange occurs. In terms of method of operation, retailing includes store and direct marketing operations. Outlets also vary in terms of the breadth and depth of their merchandise lines. Breadth here refers to the number of different items carried, and depth refers to the assortment of each item offered. In assessing their competitive position, retail outlets should consider their position in terms of breadth of merchandise line and the amount of value added, which is the service level and method of operation (Berkowitz et al., 2000).

Major retailing trends include the shifts in which stores are most popular with consumers. Also, technology has brought retailers new opportunities and challenges. In many cases, adapting to these trends has meant offering better prices. As a result more and more organizational buyers are making purchases from retailers rather than through more traditional channels of distribution (Churchill et al., 2000). The changes taking place are changing retail formats, globalization, new retail formats, retail data base marketing, powerful or vendor relationships, value pricing and low cost structures, efficient organizational structures, customer focused technologies and cyber space retailing. The value of this consciousness will continue and will keep weeding out all but the retailers that best meet consumer's desire for value. In the meantime, big suppliers are helping such mid-price as supermarkets look for ways to keep their costs down so they can offer lower prices. Today, more than ever, technology offers retailing opportunities to expand the way they communicate with and sell to customers.

Strategic management entails deciding what things are right for company under some given set of consumer expectations and competitive circumstances. Davidson et al (2000) specify strategic management as the process of deciding on the mission of the enterprise, the basic goals and objectives that it seeks to achieve, and the major strategies that will govern the use of firm's resources to achieve its objectives.
A fully developed retail market strategy identifies: the specific markets and market segments that the firm intends to pursue, the consumer and competitive performance that the firm desires in its selected markets, the specific means by which the firm intends to appeal to its target customers and establish its competitive position. The growing complexity of large, diversified retail enterprises, the rapid change in consumer markets, and the intensifying competitive environment make it imperative that the retail firms have a thoroughly well thought out strategic plan detailing how it intends to capture the target market.

\section{RESEARCH METHODOLOGY}

The proposed study employed a descriptive design. The study intended to determine what retail marketing strategies, where and how the bottling companies in Kenya have adopted and whether they have led to a sustainable competitive advantage. Many studies have utilized descriptive design in the related studies (Mazrui, 2003). The populations of interest were the marketing executives in ten (10) selected bottling companies in Nairobi Kenya.

Table 1: Study Population

\begin{tabular}{|l|l|}
\hline Company & $\begin{array}{l}\text { No. of Marketing } \\
\text { Executives }\end{array}$ \\
\hline African Spirits Limited & 22 \\
\hline Delmonte Kenya Limited & 45 \\
\hline East Africa Breweries Limited & 70 \\
\hline Excel Chemicals Limited & 15 \\
\hline Grange Park Limited & 11 \\
\hline GlaxoSmithkline Limited & 30 \\
\hline Keroche Industries Limited & 42 \\
\hline Kenya Wine Agencies Limited & 25 \\
\hline Milly Fruit Processors & 12 \\
\hline $\begin{array}{l}\text { Nairobi Bottling Company } \\
\text { Limited }\end{array}$ & 75 \\
\hline \multicolumn{1}{|c|}{ Total } & 347 \\
\hline
\end{tabular}

(Source: Research Data, 2012)

A population of 347 marketing executives from 10 bottling companies in Kenya was used in the study. Stratified Random Sampling was employed to determine the sample of 40 marketing executives.

Table 2: Sample Size

\begin{tabular}{|l|c|c|c|}
\hline \multicolumn{1}{|c|}{ Company } & Population & Ratio & $\begin{array}{c}\text { Sample } \\
\text { Size }\end{array}$ \\
\hline African Spirits Limited & 22 & 0.12 & 3 \\
\hline $\begin{array}{l}\text { Delmonte Kenya } \\
\text { Limited }\end{array}$ & 45 & 0.12 & 5 \\
\hline $\begin{array}{l}\text { East Africa Breweries } \\
\text { Limited }\end{array}$ & 70 & 0.12 & 8 \\
\hline $\begin{array}{l}\text { Excel Chemicals } \\
\text { Limited }\end{array}$ & 15 & 0.12 & 2 \\
\hline Grange Park Limited & 11 & 0.12 & 1 \\
\hline
\end{tabular}




\begin{tabular}{|l|c|c|c|}
\hline $\begin{array}{l}\text { GlaxoSmithkline } \\
\text { Limited }\end{array}$ & 30 & 0.12 & 4 \\
\hline $\begin{array}{l}\text { Keroche Industries } \\
\text { Limited }\end{array}$ & 42 & 0.12 & 5 \\
\hline $\begin{array}{l}\text { Kenya Wine Agencies } \\
\text { Limited }\end{array}$ & 25 & 0.12 & 3 \\
\hline Milly Fruit Processors & 12 & 0.12 & 1 \\
\hline $\begin{array}{l}\text { Nairobi Bottling } \\
\text { Company Limited }\end{array}$ & 75 & 0.12 & 8 \\
\hline Total & 347 & & 40 \\
\hline
\end{tabular}

(Source: Research Data, 2012)

Both primary and secondary data was collected for the study. Primary data was collected by use of a structured Likert scale questionnaire while secondary data was collected from the books of accounts, sales reports, market segments and other periodical reports that indicate the performance of companies.

\section{DATA ANALYSIS AND FINDINGS}

Table 3: Marketing strategies fitting into organizations marketing plan

\begin{tabular}{|l|r|r|r|r|}
\hline Strategy & N & Mean & $\begin{array}{c}\text { Std. } \\
\text { Deviation }\end{array}$ & Variance \\
\hline $\begin{array}{l}\text { We have a clearly } \\
\text { defined strategy; our } \\
\text { products are well } \\
\text { positioned and } \\
\text { obviously different }\end{array}$ & 40 & 3.22 & 1.074 & 1.153 \\
\hline $\begin{array}{l}\text { Our positioning is } \\
\text { well known by our } \\
\text { sales force and they } \\
\text { can easily } \\
\text { differentiate us from } \\
\text { our competitors }\end{array}$ & 40 & 3.80 & 1.285 & 1.651 \\
\hline $\begin{array}{l}\text { The economy is } \\
\text { mainly responsible } \\
\text { for our current } \\
\text { situation }\end{array}$ & 40 & 3.35 & 1.167 & 1.362 \\
\hline $\begin{array}{l}\text { Competition is } \\
\text { stronger; our main } \\
\text { rival is catching up } \\
\text { with us and we are } \\
\text { unsure how to protect } \\
\text { and grow our market } \\
\text { share }\end{array}$ & 40 & 3.68 & 1.269 & 1.610 \\
\hline $\begin{array}{l}\text { Our market share has } \\
\text { been steadily } \\
\text { declining, not sure to } \\
\text { turn things round or } \\
\text { if it can be done }\end{array}$ & 40 & 3.50 & 1.219 & 1.487 \\
\hline $\begin{array}{l}\text { (Source Research } \\
\text { Dater }\end{array}$ & $2012)$ & & \\
\hline
\end{tabular}

\section{(Source: Research Data, 2012)}

Majority of the respondents felt that marketing strategies fit to the organizations marketing plan by positioning their sales force and they can easily differentiate it from their competitors with a mean of 3.80. This was followed by market share having declined steadily and they were unsure of turning things round. The economy was identified as responsible for the current situation with a mean of 3.35 while those who felt that they have clearly defined strategy and that their products are well positioned and different had a mean of 3.22. This suggest to a strong consensus on the organizations fit of marketing strategies vis-a- vis the marketing plan at the bottling companies.

Table 4: Marketing strategies fitting into organizations marketing plan

\begin{tabular}{|l|r|r|r|r|}
\hline $\begin{array}{l}\text { Retail } \\
\text { marketing } \\
\text { strategies can } \\
\text { do without } \\
\text { financial data }\end{array}$ & \multicolumn{1}{|c|}{$\mathbf{N}$} & Mean & \multicolumn{1}{c|}{$\begin{array}{r}\text { Std. } \\
\text { Deviation }\end{array}$} & Variance \\
\hline Financial data & 40 & 2.08 & 1.163 & 1.353 \\
\hline $\begin{array}{l}\text { Management } \\
\text { accounting data }\end{array}$ & 40 & 2.28 & 1.154 & 1.333 \\
\hline Pricing data & 40 & 2.35 & 1.189 & 1.413 \\
\hline Product data & 40 & 2.78 & 1.230 & 1.512 \\
\hline $\begin{array}{l}\text { Research and } \\
\text { development } \\
\text { data }\end{array}$ & 40 & 2.30 & 1.181 & 1.395 \\
\hline Sales data & 40 & 2.58 & 1.259 & 1.584 \\
\hline $\begin{array}{l}\text { Distribution } \\
\text { data }\end{array}$ & 40 & 2.35 & 1.122 & 1.259 \\
\hline $\begin{array}{l}\text { Advertising } \\
\text { data }\end{array}$ & 40 & 2.23 & 1.025 & 1.051 \\
\hline $\begin{array}{l}\text { Sales promotion } \\
\text { data }\end{array}$ & 40 & 2.53 & 1.176 & 1.384 \\
\hline $\begin{array}{l}\text { Merchandising } \\
\text { data }\end{array}$ & 40 & 3.00 & 1.261 & 1.590 \\
\hline Market data & 40 & 2.53 & 1.132 & 1.281 \\
\hline $\begin{array}{l}\text { Valid N } \\
\text { (listwise) }\end{array}$ & 40 & & & \\
\hline Source: Research & & & & \\
\hline
\end{tabular}

(Source: Research Data, 2012)

Majority of the respondents felt merchandising data fits well into marketing strategy with a mean of 3.00. Those that felt product data is important in marketing strategies followed with a mean of 2.78 . Respondents that believed sales data was important were next. Other portions of response came from those who felt that sales promotion data, market data, pricing data, distribution data, research and development data, management accounting data, advertising data, and financial data were important in retail marketing strategies in the organization with a mean of $2.53,2.35,2.30,2.28$, and 2.08 respectively.

\section{CONCLUSION}

From the data analysis, it was established that most of the marketing executives were comfortable with their marketing plans, with $52.5 \%$ stating that they somewhat agree that they had clearly defined strategies and their products well defined. $55 \%$ of the marketing executives estimate that the economy contributed to their current situation in as far as marketing was concerned. Competition and the firm's response to it were highly rated as factors impacting on the firms marketing plan. Majority of the marketing executives have clear ideas of leads and sales pipelines. They stated that they can always tell what's coming in and what deals their representatives were working on. Most stated that their sales process is well documented and consistent between everyone and felt it was easy for new employees to integrate into the organization. 
The respondents gave candid views on effectiveness of retail marketing efforts. This ranged from telemarketing, cold calling, electronic media adverting, web presence, creation of market networks, brand and product promotion. All of the marketing executives stated that they often apply the aforementioned retail marketing activities. Many of respondents accepted that the marketing plan should be implemented only after a marketing strategy has been devised. A majority of the marketing executives accept that televisions, radio, newspaper, magazine, internet and mobiles were all very suitable for implementing retail marketing strategies for gaining organizational competitiveness in the bottling sector. Data collection, analysis and interpretation are an important aspect in retail marketing activities. Retail marketing strategies need a well thought out and calculated implementation plan.

\section{REFERENCES}

[1] Alias, R., Liana, M. \& Yacob, R. (2010), Consumers Perceptions and Attitudes towards Safety Beef Consumption, The IUP Journal of Marketing Research, Vol-9, No.4, pp 29-50

[2] Ansoff, H. I. \& McDonnell, E. J. (1990). Implanting Strategic Management ( $2^{\text {nd }} E d$.). London, Great Britain: Prentice Hall.

[3] Andrews, K. (1971). The Concept of Corporate Strategy Homewood, Illinois Dow-Jones-Irwin: Publishers.

[4] Berkowitz, Eric, Caron, R., Hartley, S., Rudelius, W. (2000) Marketing Boston: Irwin/McGraw-Hill: 110.

[5] Chandler, A. (1962). Strategy and Structure: Chapters in the History of American Industrial Enterprise. Cambridge Massachusetts, MIT Press: Publishers.

[6] Chaston, I. (2004). Knowledge Based Marketing: The Twenty-First Century Competitive Edge. Tejewar Singh for Response Books: Publisher

[7] Churchill, A.G, et al. (2000). Sales Force Management Boston: Irwin McGraw-Hill, 6a ed. 727, p.

[8] Davidson, R. W., Sweeney J. D. \& Stampel, W. R. (2000) Retailing Management USA: John Willey $\&$ Sons.

[9] Gerry, J. (1987). Business Strategy and Retailing USA: John Willey \& Sons.
[10] Girad, R. (2005). Corporate Profile Coca-Cola Company Polaris Institute Research: Author.

[11] Gluek, F. W. \& Juach L. R. (1984) Business Policy and Strategic Management McGraw-Hill, Inc

[12] Jaworski, B.J. \& Kohli, A.K.(1993) "Market Orientation Antecedents and Consequences" Journal of Marketing Vol. 57 : 53-70.

[13] Kamanu, K. (2004). The extent to which commercial banks have adopted and implemented Integrated marketing University of Nairobi Unpublished MBA research project

[14] Kibera, F. N. \& Waruingi, B. C. (2007) Fundamentals of Marketing: An African perspective. Kenya Literature Bureau: Publishers.

[15] Kotler, P. (2000). Marketing Management, New Delhi: Prentice Hall of India.

[16] Kotler P. (2003). Marketing Management (11 $1^{\text {th }}$ Ed.). New Delhi: Pearson education.

[17] Malhotra, N. \& Dash, S. (2009), Marketing Research, 5th Edition, Pearson publications Limited, New Delhi, pp 615-617

[18] Matin, K. (2007) Consumer Behavior and Advertising Management New Age International (Formerly Wiley Eastern Ltd.): Publishers.

[19] Mazrui S. (2003). Marketing approaches used by managers to address customer service

[20] challenges in Banking in Kenya University of Nairobi Unpublished MBA research project

[21] Members Directory (2008) A directory of the Kenya Association of Manufacturers www.kam.co.ke

[22] Mercer, D. (1997) New Marketing Practice: Rules for success in a changing world. Penguin Books Ltd: Publishers.

[23] Mintzberg, H. (1987). Management review: The Strategy Concept I, Five P's for Strategy. California. 30(1)

[24] Oliver, R. L. (1993), "Cognitive, Affective, and Attribute Bases of the Satisfaction Response," Journal of Consumer Research,20 (3), 418-30.

[25] Sternquist, B. \& Jin, B. (1998), "South Korean retail industry: government's role in retail liberalization', International Journal of Retail \& Distribution Management, Vol. 26 No. 9, pp. 34553. 